\title{
KEPEMIMPINAN BERBASIS ISLAMI DALAM MENINGKATKAN MUTU PENGELOLAAN PERGURUAN TINGGI
}

\author{
${ }^{1}$ Astuti, ${ }^{2}$ Saril \\ ${ }^{1}$ Institut Agama Islam Negeri (IAIN) Bone \\ e-mail: astutiabbas69@gmail.com \\ ${ }^{2}$ Institut Agama Islam Negeri (IAIN) Bone \\ e-mail: saril1586@gmail.com
}

\begin{abstract}
ABSTRAK
This study discusses Islamic-based leadership in improving the quality of Higher Education management at IAIN Bone and IAIN Pare-Pare. The problems examined in this research are: (a) How is the Islamic-based leadership approach in improving the quality of Higher Education management at IAIN Bone and IAIN Pare-Pare, (b) How is the quality of Higher Education in IAIN Bone and IAIN Pare-Pare. The results showed that the Islamic-based leadership approach in improving the quality of Higher Education management at IAIN Bone and IAIN Pare-Pare applied Islamic values both in decision making, division of labor, direction, communication, giving awards, and giving sanctions. The values applied in the development of Higher Education management at IAIN Bone and IAIN Pare-Pare such as; trustworthy, honesty, respect, deliberation, consistency/discipline, commitment in carrying out duties and responsibilities, gentle, firm. humanist, firm attitude, meticulous, hard work, guiding, and always motivating. Likewise, the Islamic culture which is always used as the basis for the management of tertiary institutions, especially in IAIN Pare-Pare, is the malebbi warekkadana makkeade ampena (polite in speaking and ethical behavior). While at IAIN Bone is sipakatau (mutual respect, view humans as humans), sipakalebbi (mutual respect), and sipakainge (remind each other) in accordance with the values contained in IAIN Bone's vision. The quality of IAIN Bone and IAIN Pare-Pare higher education has improved from various aspects but after the transfer of status and changes in the standard of tertiary education it is always making improvements to adjust.
\end{abstract}

Keywords: Leadership, Quality, Management.

\section{PENDAHULUAN}

Pendidikan adalah proses pengembangan potensi individu menjadi potensi nyata yang diperlukan untuk menjalani kehidupan yang bermartabat baik sebagai pribadi, anggota masyarakat, warga negara, dan bahkan warga masyarakat dunia. Proses pengembangan potensi tersebut terjadi dalam lingkungan keluarga, lingkungan pendidikan formal, dunia kerja, dan masyarakat.

Institut Agama Islam Negeri sebagai lembaga pendidikan formal dan Lembaga pendidikan Islam sebagaimana lembaga pada umumnya adalah agen peradaban dan perubahan sosial. Lembaga pendidikan yang pada saat ini berada dalam atmosfir modernisasi dan globalisasi dituntut untuk mampu memainkan perannya secara dinamis dan proaktif. Keberadaannya diharapkan mampu memberikan kontribusi dan perubahan dan perubahan positif yang berarti bagi perbaikan dan kemajuan peradaban umat Islam, baik pada tataran intelektual teoretis maupun praktis. Pendidikan Islam bukan hanya sekedar proses transformasi nilai-nilai moral untuk membentengi diri dari akses 
negatif globaslisasi dan modernisasi. Tetapi, yang paling urgen adalah bagaimana nilai-nilai moral yang telah ditanamkan lewat pendidikan Islam tersebut mampu berperan aktif sebagai generator yang memiliki power pembebas dari tekanan dan himpitan keterbelakangan sosial budaya, kebodohan, ekonomi, dan kemiskinan di tengah mobilitas sosial yang begitu cepat.

Perguruan Tinggi yang mampu memberikan perbaikan dan kemajuan peradaban sangat dipengaruhi oleh kesiapan semua komponen-komponen di Perguruan Tinggi baik kesiapan akademik maupun non akademik. Oleh karena itu, sangat dibutuhkan kepemimpinan yang berorientasi pada mutu.

Dzaujak Ahmad menyatakan bahwa mutu pendidikan merupakan kemampuan sekolah dalam pengelolaan secara operasional dan efisien terhadap komponen-komponen yang berkaitan dengan sekolah sehingga menghasilkan nilai tambah terhadap komponen tersebut menurut norma/standar yang berlaku. Artinya, konsep mutu dalam pengelolaan lembaga pendidikan Islam seharusnya benar-benar tanggap dan konsisten terhadap mutu pendidikan Islam tersebut, baik mutu manajemen yang dilihat dari proses maupun mutu kegiatan belajar mengajar (KBM) sebagai produk pelayanan jasa pendidikan Islam untuk pemakai dalam proses (internal customer) maupun pemakai hasil akhir (eksternal customer). ${ }^{l}$

Institut Agama Islam Negeri (IAIN) Bone dan IAIN Pare-Pare merupakan Perguruan Tinggi Islam Negeri di Sulawesi Selatan yang sangat diminati oleh masyarakat yang nampak dari peminat masyarakat meningkat dari tahun ketahun. Perguruan Tinggi ini diharapkan akan menjadi pencetak generasi yang akan menjadi pejuang agama Islam dan pengembang bangsa dan Negara. Hal tersebut akan terwujud jika pengelolaan lembaga pendidikan berada di tangan pemimpin Perguruan Tinggi yang berpegang teguh pada nilai-nilai Islami. Dari fenomena yang ada maka peneliti tertarik untuk meneliti bagaimana kepemimpinan berbasis islami dalam peningkatan mutu pengelolaan Perguruan Tinggi di IAIN Bone dan IAIN Pare-Pare.

\section{METODE PENELITIAN}

Penelitian ini merupakan penelitian kualitatif. Penelitian kualitatif mempunyai sifat artistic, naturalistic, interpretative, dan interpretative. Pengumpulan data dalam penelitian ini dilakukakan dengan teknik observasi, wawancara yang mendalam, dan Dokumentasi. Adapun langkah-langkah pengolahan dan analisis data dalam penelitian ini adalah: Reduksi Data, menyajikan data, dan Veryfikasi.

\section{HASIL DAN PEMBAHASAN}

\section{Pendekatan Kepemimpinan Berbasis Islami dalam Peningkatan Mutu Pengelolaan Perguruan Tinggi IAIN Bone dan IAIN Pare-Pare.}

Kepemimpinan merupakan suatu suatu proses untuk memengaruhi, mengarahkan, membimbing, menuntut para anggota untuk melaksanakan kegiatan sehingga tujuan yang sudah ditetapkan dapat terwujud. Pemimpin dalam melaksanakan kepemimpinannya dipengaruhi oleh berbagai faktor, diantaranya jabatan, kemampuan, bawahan, dan situasi dan kondisi. Oleh karena itu, seorang pemimpin di dalam kepimpinannya memang memiliki otoritas untuk memerintah, mengarahkan dan kalau perlu memaksa dengan memperhatikan faktor kondisi bawahan dan situasi dan kondisi yang berlangsung. Di samping hal tersebut, kemampuan baik dari aspek kemampuan

${ }^{1}$ Dzaujak Ahmad, Penunjuk Peningkatan Mutu pendidikan di sekolah Dasar (Jakarta: Depdikbud, 1996), h. 8. 
pribadi, kemapuan manajerial, kemampuan kewirausahaan, dan kemampuan sosial merupakan hal yang tak kalah pentingnya harus dimiliki oleh pimpinan.

Institut Agama Islam Negeri (IAIN) Bone dan IAIN Pare-Pare merupakan Perguruan Tinggi yang mengalami transformasi dari Sekolah Tinggi Agama Islam Negeri (STAIN) ke IAIN, maka membutuhkan kemauan, kerja sama, dan kemampuan yang tinggi dari semua pihak yang terkait guna mewujudkan tata kelola yang akuntabel.

Pengelolaan Perguruan Tinggi yang akuntabel sangat ditentukan oleh pimpinan, baik itu pimpinan institusi, pimpinan fakultas, pimpinan prodi, dan pimpinan unit-unit. Oleh karena itu, Pimpinan hendaklah memiliki sifat-sifat yang terpuji sebagaimana Rasulullah dalam kepemimpinanya memiliki sifat siddiq, fathonah, tabliq, dan amanah.

Dalam upaya mewujudkan mutu pengelolaan ke dua Perguruan Tinggi ini, maka menempuh berbagai pendekatan, yaitu:

a. Pendekatan kepemimpinan yang berintegritas,

Integritas berkaitan dengan konsistensi tindakan, metode, nilai, ukuran-ukuran, dan prinsipprinsip. Dengan demikian pemimpin yang berintegritas memiliki pribadi yanag jujur dan karakter yang kuat. Oleh karena itu, pimpinan Perguruan Tinggi dalam melaksanakan kepemimpinanya memiliki sifat tersebut. Adapun bentuk integritas kepemimpinan dalam mengembangkan pengelolaan Perguruan Tinggi tersebut adalah kejujuran, konsistensi/disiplin, kebersamaan, komitmen, mengayomi, mengarahkan bawahan dengan menelakukan pendekatan humanis, koordinasi, memberikan kepercayaan kepada bawahan, melaksanakan controlling, sikap yang tegas, kerja cepat, kerja Keras, cermat, membimbing, Ing ngarso Sung Ttulodo, Ing Madyo Mangun Karso, dan Tut Wuri Handayan.

Sebagaimana firman Allah dalam Surah Al-Maidah (05) ayat 8.

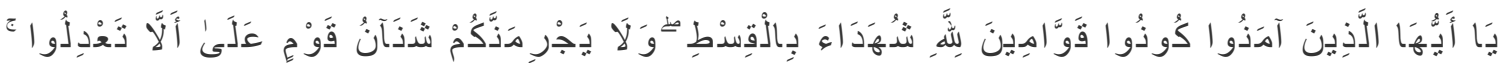

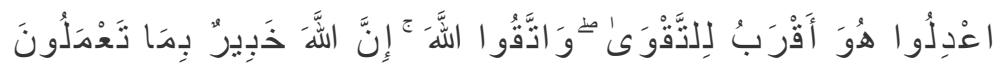

Terjemahnya : Hai orang-orang yang beriman hendaklah kamu jadi orang-orang yang selalu menegakkan (kebenaran) Karena Allah, menjadi saksi dengan adil. dan janganlah sekali-kali kebencianmu terhadap sesuatu kaum, mendorong kamu untuk berlaku tidak adil. berlaku adillah, Karena adil itu lebih dekat kepada takwa. dan bertakwalah kepada Allah, Sesungguhnya Allah Maha mengetahui apa yang kamu kerjakan. ${ }^{2}$

Dari makna yang terkandung dari Surah Al-Maidah (05) ayat 8 tersebut bahwa, Allah senantiasa memerintahkan untuk menegakkan kebenaran dalam melaksanakan segala perkara dengan penuh keikhlasan. Dalam ayat ini juga diterangkan bahwa bentuk kejujuran adalah menyatakan kebenaran dalam persaksian secara adil, tanpa didasari unsur apapun, kepada siapapun sekalipun terhadap musuh. Karena apabila terjadi ketidak adilan maka akan menimbulkan perpecahan karena telah hilangnya rasa percaya dari pihak lain. Oleh karena itu, pengelola Perguruan Tinggi baik ditingkat institusi, fakultas, unit-unit, atau dengan kata lain civitas akademika hendaklah menerapkan kejujuran dalam pelaksanaan tugas pokok dan fungsinya. Bentuk-bentuk kejujuran diantaranya; jujur dalam niat, jujur dalam perkataan, jujur dalam berjanji, dan jujur dalam bergama. Kejujuran itu akan akan memperluas pergaulan, hidup bermasyarakat

\footnotetext{
${ }^{2}$ Departemen Agama RI, Al-Quran dan Terjemahnya (Jakarta : doa Ibu, 2006), h. 186.
} 
dengan damai, dan mendapat ridho dari Allah swt. Oleh karena itu, Berdasarkan prinsip kejujuran pengelolaan lembaga pendidikan, maka akan terbangun citra positif di tengah masyarakat.

b. Pendekatan kepemimpinan dalam pengambilan keputusan.

Perguruan Tinggi yang maju dan berkembang merupakan salah satu indikator keberhasilan seorang pemimpin. Seorang pemimpin memiliki tanggung jawab dalam memberikan arahan, motivasi, peduli terhadap bawahan, berusaha selalu memberi solusi terhadap permasalahan yang dihadapi dan seorang pemimpin harus mampu menerapkan skala prioritas terhadap program yang akan dilaksanakan dalam suatu lembaga yang dipimpinnya.

Di dalam melaksanakan tanggung jawab dalam kepemimpinannya, maka memerlukan bentuk hubungan yang efektif, artinya hubungan manusiawi dalam kepemimpinan adalah cara seseorang pemimpin dalam memperlakukan orang yang dipimpinnya, yang akan memberikan tanggapan berupa kegiatan-kegiatan yang menunjang untuk pencapaian tujuan kelompok. Kegiatan-kegiatan itu bukan sesuatu yang statis, tetapi dapat berubah dan berkembang sehingga aktualisasi organisasi menjadi dinamis. Adanya hubungan yang manusiawi, maka interaksi antara seseorang dengan orang membutuhkan rasa saling memahami, saling menyayangi, dan saling menghormati dengan prinsip utama adanya musyawarah, seperti dalam firman Allah swt dalam surah Ali ‘ Imran (3) ayat 159.

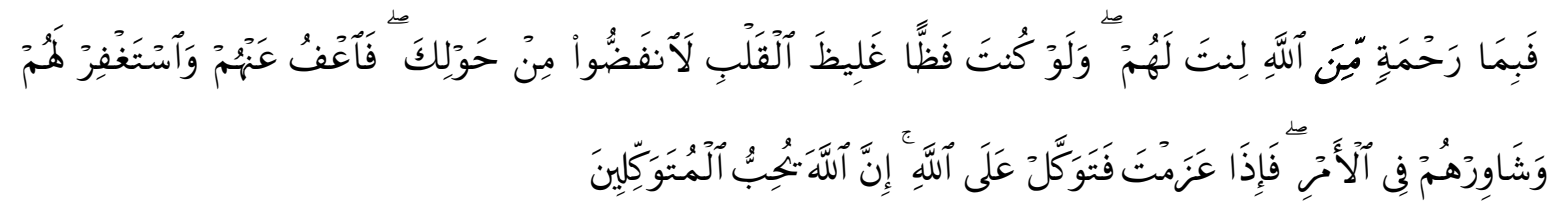

Terjemahnya : Maka disebabkan rahmat dari Allah-lah kamu berlaku lemah lembut terhadap mereka. sekiranya kamu bersikap keras lagi berhati kasar, tentulah mereka menjauhkan diri dari sekelilingmu. Karena itu maafkanlah mereka, mohonkanlah ampun bagi mereka, dan bermusyawaratlah dengan mereka dalam urusan itu. Kemudian apabila kamu Telah membulatkan tekad, Maka bertawakkallah kepada Allah. Sesungguhnya Allah menyukai orang-orang yang bertawakkal kepada-Nya. ${ }^{3}$

Menciptakan hubungan manusia yang efektif merupakan alat dalam kepemimpinan. Oleh karena itu, seorang pimpinan hendaklah manusiawi memperlakukan bawahannya, baik dalam pengambilan keputusan dalam pengembangan Perguruan Tinggi, mengarahkan, membimbing, memerintah, pemberian pekerjaan, pemberian hukuman, dan lain-lain.

Adapun pendekatan kepemimpinan dalam pengambilan keputusan pada pengembangan pengelolaan Perguruan Tinggi tersebut adalah mengarah pada pengembangan mutu Perguruan Tinggi, keputusan yang mengarah pada pencapain Visi Misi Perguruan Tinggi dengan melibatkan pihak yang terkait, penetapan keputusan dalam kondisi emosi yang stabil dengan memperhatikan manfaat dan mudaratnya serta senantiasa meminta petunjuk kepada Allah, dan tepat waktu. Oleh Karena itu, pemimpin wajib memberikan contoh yang baik bagi orang-orang yang dipimpinnya dalam pengambilan keputusan. Sebagaimana firman Allah dalam surah Al-Ahzab (33) ayat 21.

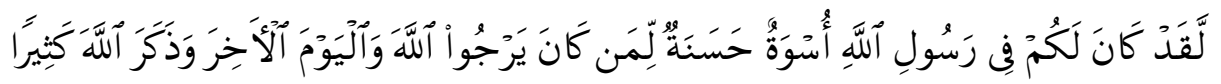

\footnotetext{
${ }^{3}$ Departemen Agama RI, Al-Quran dan Terjemahnya (Jakarta : Doa Ibu, 2006), h. 118
} 
Terjemahnya : Sesungguhnya Telah ada pada (diri) Rasulullah itu suri teladan yang baik bagimu (yaitu) bagi orang yang mengharap (rahmat) Allah dan (kedatangan) hari kiamat dan dia banyak menyebut Allah. ${ }^{4}$

Pengambilan keputusan penting bagi pemimpin pendidikan, karena proses pengambilan keputusan mempunyai peran penting dalam memotivasi, kepemimpinan, komunikasi, koordinasi, dan perubahan organisasi. Oleh karena itu, pemimpin harus memiliki keterampilan mengambil keputusan secara cepat, tepat, efektif, dan efisien. Sebagaimana menurut Mintzberg dalam Husaini Usman bahwa, ada tiga tahapan dalam proses pengambilan keputusan, yaitu (1) Tahap identifikasi, (2) Tahap pengembangan, dan (3) Tahap Pemilihan. Pada tahap identifikasi, pengambil keputusan memahami masalah dan peluang membuat diagnosis. Pada tahap pengembangan, pengambil keputusan mencari standar prosedur yang tersedia atau pemecahan masalah sebagai desain baru, kadang-kadang tahap ini mengandung trial and error. Pada tahap pemilihan, pengambil keputusan dapat memilih dengan mengunakan pertimbangan, analisis logis, basis sistematis, atau bargain.

c. Pendekatan kepemimpinan dalam Pembagian kerja dan pengarahan.

Efisiensi dan efektifitas pelaksanaan pekerjaan sangat di tentukan oleh sumber daya manusianya. Pekerjaan yang ada di Perguruan Tinggi sangat banyak dan pekerjaan itu dikelompokkelompokkan ke unit-unit tertentu dan pekerjaan tersebut dibagi secara jelas kesetiap personal. Pekerjaan itu harus di bagi karena manusia memiliki keterbatasan kemampuan, keterbatasan waktu, keterbatasan pengetahuan, dan keterbatasan perhatian.

Pendekatan kepemimpinan dalam pembagian kerja dan pengarahan bawahan dalam mewujudkan mutu pengelolaan di Perguruan Tinggi tersebut adalah 1) Pembagian kerja disesuaikan dengan jabatan fungsional, 2) Pembagian kerja disesuaikan dengan keamampuan dan keahlian personal, 3) Pembagian kerja berdasarkan pengalaman dan minat. Adapun pengarahan dilaksanakan dengan : 1) mengedepankan pendekatan humanis, 3) kenyamanan dari bawahan, 4) menjunjung nilai Malebbi Warekkadana Makkeade Ampena (sopan tutur katanya dan berkarakter perilakunya).

Jadi apabila pimpinan menerapkan nilai seperti hal tersebut, maka akan menimbulkan kenyamana dalam bekerja, membangun motivasi kerja, dan tanggung jawab dalam bekerja. Hal tersebut timbul karena tidak terjadi kekhawatiran dalam bekerja karena pengarahan jelas dan tidak menimbulkan perasaan tertekan. Sebagaimana firman Allah dalam QS Al-Imran (3) Ayat 104.

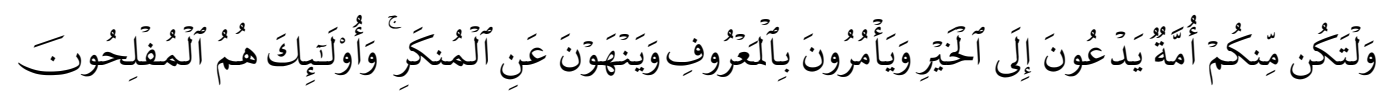

Terjemahnya : Dan hendaklah ada di antara kamu segolongan umat yang menyeru kepada kebajikan, menyuruh kepada yang ma'ruf dan mencegah dari yang munkar merekalah orang-orang yang beruntung. ${ }^{5}$

Sebagaimana juga Hadits tentang bahaya menyerahkan urusan kepada yang bukan ahlinya, telah ditegaskan oleh Nabi Muhammad shallallahu 'alaihi wa sallam.

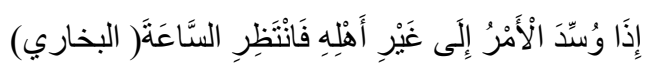

Artinya." Apabila perkara diserahkan kepada orang yang bukan ahlinya maka tunggulah kiamat. (HR Al-Bukhari dari Abi Hurairah).

Al-Munawi dalam kitab Faidhul Qadir menjelaskan: Apabila hukum yang berkaitan dengan agama seperti kekhalifahan dan rangkaiannya berupa kepemimpinan, peradilan, fatwa,

\footnotetext{
${ }^{4}$ Departemen Agama RI, Al-Quran dan Terjemahnya (Jakarta : Doa Ibu, 2006), h. 767.
}

${ }^{5}$ Departemen Agama RI, Al-Quran dan Terjemahnya (Jakarta : Doa Ibu, 2006), h 105. 
pengajaran dan lainnya diserahkan kepada orang yang bukan ahlinya, yakni apabila (pengelolaan urusan) perintah dan larangan diserahkan kepada yang bukan ahlinya, maka tunggulah kiamat, sebab hal itu sudah datang tanda-tandanya. Ini menunjukkan dekatnya kiamat, sebab menyerahkan urusan dalam hal amar (perintah) dan nahi (larangan) kepada yang tidak amanah, rapuh agamanya, lemah Islamnya, dan (mengakibatkan) merajalelanya kebodohan, hilangnya ilmu dan lemahnya ahli kebenaran untuk pelaksanaan dan penegakannya, maka itu adalah sebagian dari tanda-tanda kiamat. ${ }^{6}$

d. Pendekatan dalam berkomunikasi

Komunikasi merupakan hal yang tidak kalah pentingnya dalam organisasi. Komunikasi bagaikan darah dalam tubuh manusia yang harus senantiasa mengalir ataupun tercipta. Komunikasi yang harus tercipta dalam Perguruan Tinggi adalah komunikasi internal maupun komunikasi eksternal. Cara pimpinan berkomunikasi ke bawahan akan sangat menentukan terbangunnya sutu proses kerja sama yang baik. Oleh karena itu, komunikasi harus jelas dengan mempertimbangkan cara berkomunikasi yang tepat baik secara langsung maupun tidak langsung. Di samping itu, etika dalam menyampaikan komunikasi merupakan hal penting yang harus diperhatikan oleh pimpinan sehingga bawahan akan terpengaruh dengan apa yang menjadi inti dari komunikasi itu sendiri. Sebagaimana Hadits dari Imam Ali bin Husain as-Sajjad dalam Risâlah al-Huqûq-nya dimana beliau berkata dalam bagian pembahasan tentang menjaga sopan santun di hadapan guru:

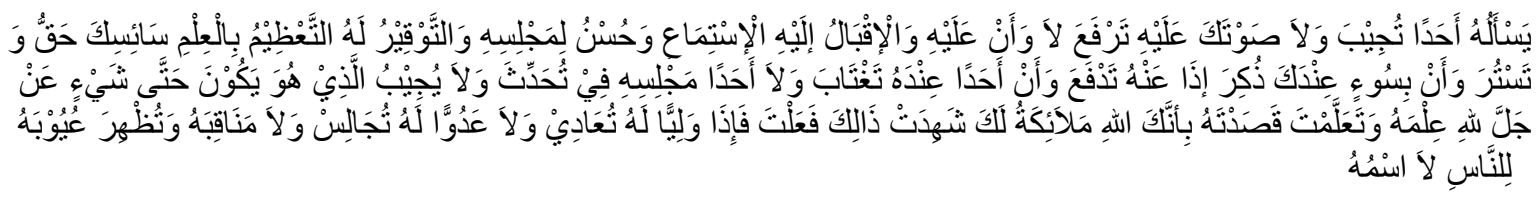

Artinya : Dan hak pemimpin (pembimbing)mu dalam ilmu adalah penghormatan kepadanya, mengagungkan majlisnya dan serta mendengarkannya dengan baik, serius menghadap kepadanya, tidak meninggikan suara terhadapnya, tidak menjawab seseorang yang bertanya kepadanya sampai dia menjawabnya, tidak berbicara di majlisnya, membelanya ketika ada yang yang menyebutkan keburukannya kepadamu, menutupi aibnya dan menampakkan kebaikannya, tidak duduk bersama musuhnya dan tidak memusuhi temannya, apabila kamu melakukan hal itu maka malaikat Allah akan bersaksi bahwa kamu berniat mempelajari ilmunya karena Allah bukan karena manusia. (Al-Mahajjah al-Baydhâ'; Al Faidh al Kâsyâni, juz 3 hal. 450, Bab Adab asShuhbah wal Mu'asyarah).

Berdasarkan hasil hasil penelitian tentang pendekatan kepemimpinan dalam berkomunikasi dalam mengembangkan mutu pengelolaan di perguruan Tinggi tersebut adalah sebagai berikut :

1) Berkomunikasi dengan sopan (beretika).

2) Menjaga kenyamanan dan tidak menimbulkan ancaman.

3) Tegas.

4) lemah lembut tanpa menyinggung perasaan.

5) Berempati.

e. Pendekatan dalam pengawasan

Pengawasan adalah proses pengamatan dan pengukuran suatu kegiatan operasional dan hasil yang dicapai dibandingkan dengan standar yang telah ditetapkan sebelumnya yang terlihat dalam rencana. Pengawasan dilakukan dalam usaha menjamin bahwa semua kegiatan terlaksana sesuai dengan kebijaksanaan, strategi, keputusan, rencana dan program kerja yang telah dianalisis,

${ }^{6}$ Al-Munawi, Faidhul Qadir, juz 1, (Darul Fikr, Beirut, cetakan 1, 1416H/ 1996M), h. 563-564. 
dirumuskan, dan ditetapkan sebelumnya. Pengawasan baerfungsi untuk mengukur tingkat efektivitas kerja personal dan tingkat efisiensi penggunaan metode dan alat tertentu dalam usaha mempercepat tujuan organisasi, sehingga pengawasan sesungguhnya merupakan alat pengukuran terhadap efektivitas, efisiensi, dan produktivitas organisasi

Pendekatan kepemimpinan dalam pengawasan guna membangun pengelolaan Perguruan Tinggi Yang bermutudi perguruan tinggi tersebut adalah: 1) Dilakukan secara terstruktur yang disesuaikan dengan tupoksinya. 2) Pengawasan dilakukan secara kontinyu, 3) Ruang lingkup pengawasan mencakup semua komponen perguruan Tinggi baik aspek akademik dan non akademik, 4) membangun pengawasan melekat.

Sebagaimana firman Allah dalam QS Al-Mukminun (23) : 3 .

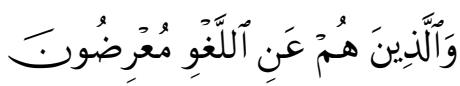

Terjemahnya :Dan orang-orang yang menjauhkan diri dari (perbuatan dan perkataan) yang tiada berguna. ${ }^{7}$

Ayat di atas bermakna bahwa seorang muslim harus produktif dalam segala hal. Produktif dalam berbicara dan bekerja. Ayat tersebut juga menegaskan bahwa menjaga amanah dan memenuhi janji adalah bagian dari budaya islami. Jika setiap pengelolah Perguruan Tinggi menepati janji atau bekerja sesuai dengan tugas pokok dan fungsinya maka hal tersebut merupakan hal yang luar biasa, karena akan membawa perubahan ke arah yang lebih baik dan visi dan misi Perguruan Tinggi dapat terwujud secata maksimal.

f. Pendekatan dalam Pemberian Kesejahteraan

Organisasi merupakan wadah terjadinya kerjasama orang-orang dalam mewujudkan tujuan yang sudah ditentukan sebelumnya. Begitupula Perguruan Tinggi terdiri dari tenaga pendidik dan kependidikan dan saling berinteraksi dalam mewujudkan visi dan misi institusi. Oleh karena itu, perlu ada keseimbangan dengan kesejahteraan yang diterimanya.

Timbulnya kesejahteraan tidak semata-mata disebabkan oleh imbalan yang berbentuk material tetapi juga terkait dari keadaaan lingkungan dan suasana nyaman. Oleh karena itu, dalam mewujudkan kenyamanan tersebut, maka pimpinan menfasilitasi dalam pelaksanaan pekerjaan, baik dari sarana pendukung maupun interaksi sosial yang senantiasa harmonis. Interaksi sosial yang harmonis terwujud dari budaya islami yang selalu di dijadikan acuan dalam berinteraksi mulai dari pimpinan sampai jajaran yang paling rendah.

Sebagaimana firman Allah dalam Surah An-Najm (53) ayat 39:

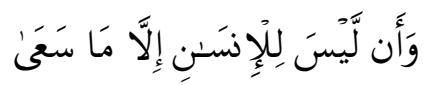

Terjemahnya :Dan bahwasanya seorang manusia tiada memperoleh selain apa yang telah diusahakannya. ${ }^{8}$

Dari ayat tersebut dipahami bahwa akan berbanding lurus antara hasil dengan usaha yang telah dilakukan. Oleh karena itu, hendaklah bersungguh-sungguh dalam melaksanakan pekerjaan. Begitupula apabila manusia melaksanakan kebaikan maka akan mendapat imbalan di daunia maupun diakhirat kelak.

g. Pendekatan kepemimpinan dalam Pemberian Hukuman

Pimpinan yang berani adalah pimpinan yang mampu menghadapi tekanan-tekanan yang tidak sesuai dengan nilai yang seharusnya dimiliki pleh bawahan, bertindak adil dalam mengambil keputusan bagi pegawai yang melanggar peraturan. Pada prinsipnya, sanksi yang diberikan

\footnotetext{
${ }^{7}$ Departemen Agama RI, Al-Quran dan Terjemahnya (Jakarta : Doa Ibu, 2006), h. 610.
}

${ }^{8}$ Departemen Agama RI, Al-Quran dan Terjemahnya (Jakarta : doa Ibu, 2006), h. 787. 
merupakan upaya untuk mencegah perilaku yang menyimpang dan sebagai hukuman penjeraan untuk tidak melakukan perbuatan yang bisa merugikan. Sanksi itu merupakan hal yang tidak menyenangkan bagi sipenerima hukuman. Ngalim Purwanto membagi sanksi (punishment) menjadi dua macam yaitu :

1) Sanksi prefentif yaitu sanksi yang dilakukan dengan maksud atau supaya tidak terjadi pelanggaran. Sanksi ini bermaksud untuk mencegah agar tidak terjadi pelanggaran, sehingga hal ini dilakukannya sebelum terjadi pelanggaran dilakukan. Contoh perintah, larangan, pengawasan, perjanjian dan ancaman.

2) Sanksi represif yaitu sanksi yang dilakukan, oleh karena adanya pelanggaran, oleh adanya dosa yang telah diperbuat. Jadi sanksi itu terjadi setelah terjadi kesalahan. ${ }^{9}$

Dari pendapat di atas, maka dapat diketahui bahwa sanksi dilakukan untuk mencegah terjadinya pelanggaran dan merupakan penjeraan. Menurut Andi Nuzul Rektor IAIN Bone bahwa, hal yang dilakukan guna mewujudkan tata kelolah yang bagus adalah tidak mengedepankan pemberian sangsi tetapi penyadaran tentang pentingnya akhlak, kecerdasasan emosional, dan kecerdasan spiritual. (2019 November 2019). Menurut Kepala Biro IAIN Bone bahwa, upaya dalam mewujudkan mutu pengelolaan Perguruan Tinggi IAIN Bone adalah menciptkan kualitas kerja semua pengelolah lembaga pendidikan. Oleh karena itu, semua pegawai dituntut untuk melaksanakan dan menyelesaikan tugas yang merupakan tanggung jawabnya. Oleh karena itu, apabila ada staf yang merupakan Pegawai Negeri Sipil yang tidak membuat laporan kinerjanya maka hukuman yang diterapkan adalah menunda pembayaran tunjangan kinerja sampai pada pengumpulan laporannya. Hal tersebut dilaksanakan untuk membangun motivasi kerja dan mencegah terjadinya kelalaian dalam penyelesaian pekerjaan. Alhamdulillah setelah diterapkan aturan/kebijakan seperti itu maka hanya satu atau dua orang saja yang tidak tepak waktu dalam pengumpulan laporan kinerjanya. (2019 November 7).

Dari hasil penelitian tentang pemberian hukuman kepada pihak dosen, pegawai, dan mahasiswa di IAIN Bone dan IAIN Pare-Pare dilakukan melalui prosedur yang sudah ditentukan sesuai dengan tingkat pelanggaranya dengan menerapkan prinsip keadilan. Nilai Adil tersebut merupakan salah satu prinsip manajemen Pendidikan Islam dan juga merupakan sifat yang dimiliki oleh Rasulullah dalam kepemimimpinannya. Sebagaimana dalam Firman Allah dalam Surah AlHujurat (49) : 9 yang berbunyi:

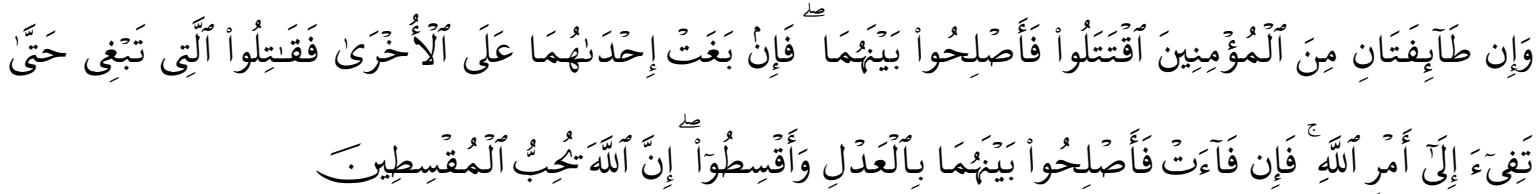

Terjemahnya : Dan kalau ada dua golongan dari mereka yang beriman itu berperang hendaklah kamu damaikan antara keduanya tapi kalau yang satu melanggar perjanjian terhadap yang lain, hendaklah yang melanggar perjanjian itu kamu perangi sampai surut kembali pada perintah Allah. kalau dia Telah surut, damaikanlah antara keduanya

${ }^{9}$ RahmanDwitiohttps://tiohamdani.wordpress.com/2014/11/26/penghargaan-dan-hukuman-dalamorganisasi-perusahaan / diakses tgl 11 November 2019. 
menurut keadilan, dan hendaklah kamu berlaku adil; Sesungguhnya Allah mencintai orang-orang yang berlaku adil. ${ }^{10}$

\section{Perkembangan Mutu Pengelolaan Perguruan Tinggi IAIN Bone dan IAIN Pare-Pare}

IAIN Bone dan IAIN Pare-Pare mengalami transformasi dari STAIN menjadi IAIN pada tahun 2018. Hal ini membuktikan bahwa ke dua Perguruan Tinggi ini mengalami perubahan dan perkembangan ke arah yang lebih baik. Dengan demikian dari perubahan tersebut maka masih banyak yang perlu dibenahi sesuai Standar Pengelolaan Perguruan Tinggi. Begitupula halnya karena standar pengelolaan perguruan tinggi juga berubah yang sebelumnya tujuh kiteria berubah menjadi sembilan kriteria.

Pengelolaan Perguruan Tinggi yang berorientasi pada mutu hendaklah mengacu pada Standar Nasional Pendidikan Tinggi. Standar Nasional Pendidikan Tinggi adalah suatu standar yang meliputi Standard Nasional Pendidikan, ditambah Stanadar Nasional penelitian,dan Standard Nasional pengabdaian kepada masyarakat. Sebagaimana juga yang tertuang dalam Peraturan Pemerintah RI Nomor 4 tahun 2014 tentang Penyelenggaran Pendidikan Tinggi dan Pengelolaan Perguruan Tinggi Bab III Pengelolaan Perguruan Tinggi pasal 23 bahwa otonomi pengelolaan pada Perguruan Tinggi meliputi:

1. Bidang akademik:

a. Penetapan norma, kebijakan operasional dan pelaksanaan pendidikan terdiri atas: persyaratan akademik mahasiswa yang akan diterima kurikulum program studi proses pembelajaran, persyaratan kelulusan, dan wisuda.

b. Penetapan aturan norma, kebijakan operasional, serta pelaksanaan penelitian dan pengabdian kepada masyarakat.

2. Bidang non akademik

a. Penetapan norma, kebijakan operasional, dan pelaksanaan organisasi terdiri atas: rencana strategis dan renana kerja tahunan; serta sistem penjaminan mutu internal.

b. Penetapan norma, kebijakan operasional, dan pelksanaan keuangan terdiri dari: membuat perjanjian dengan pihak ketiga dalam lingkup Tridharma Perguruan Tinggi; sistem pencatatan dan pelaporan keuangan sesuai dengan peraturan perundang-undangan.

c. Penetapan norma kebijakan operasional, dan pelaksanaan kemahasiswaan terdiri atas: kegiatan kemahasiswaan intrakurikuler dan ekstrakurikuler; organisasi kemahsiswaan; pembinaan bakat dan minat mahasiswa.

d. Penetapan norma kebijakan operasional, dan pelaksanaan ketenagaan terdiri atas: penugasan dan peminaan sumer daya manusia; dan penyusunan target kerja dan jenjang karir.

e. Penetapan norma keijakan operasional dan pelaksanaan pemanfaatan sarana dan prasarana terdiri atas: penggunaan sarana dan prasarana; pemeliharaan sarana dan prasarana; dan pemanfaatan sarana dan prasarana sesuai dengan ketentuan peraturan perundang-undanagan.

\footnotetext{
${ }^{10}$ Departemen Agama RI, Al-Quran dan Terjemahnya (Jakarta : doa Ibu, 2006), h. 961.
} 
Berdasarka peraturan tersebut, maka semua komponen di Perguruan Tinggi yang meliputi kegiatan akademik dan non akademik harus dikelolah secara professional. Pengelolaan yang professional akan sangat dipengaruhi oleh kemampuan seorang pemimpin dalam menggerakkan, mempengaruhi semua pihak yang terkait dalam pengelolaan tersebut.

a. Mutu Pengelolaan Bidang Akademik.

\section{Penerimaan Mahasiswa Baru.}

Mutu pengelolaan bidang akademik di Perguruan Tinggi IAIN Bone dan IAIN Pare-Pare mengalami perkembangan. Dokumen mutu akademik mulai dari dokumen penerimaan mahasiswa baru, kurikulum program studi, proses pembelajaran, kelulusan, dan wisuda telah tersedia walaupun masih ada dokumen yang membutuhkan penyempurnaan dikarenakan telah terjadi alih status dari STAIN ke IAIN.

Berdasarkan hasil penelitian, maka dapat diketahui terjadinya perkembangan mutu pengelolaan Perguruan Tinggi di IAIN Bone dan IAIN Pare-Pare khususnya pada seleksi penerimaan mahasiswa baru karena kegiatan tersebut pelaksanaannya berbasis IT dan sistem orientasi mahasiswa baru mengacu pada aturan yang terkait serta dilakukan dengan pendekatan humanis.

\section{b. Kurikulum Program Studi}

IAIN Bone memiliki empat fakultas yaitu; Fakultas Tarbiyah, Fakultas Syariah, Fakultas Ushuluddin dan Dakwah, serta Fakultas Ekonomi dan Bisnis. Fakultas Tarbiyah terdiri dari enam Program Studi yaitu; Pendidikan Agama Islam (PAI), Pendidikan Bahasa Arab (PBA), Tadris Bahasa Inggris (TBI), Manajemen Pendidikan Islam (MPI), Pendidikan Guru Madrasah Ibtidaiyah (PGMI), dan Pendidikan Islam Anak Usia Dini (PIAUD). Fakultas Syariah terdiri dari dua Program Studi yaitu, Hukum Keluarga Islam (HKI) dan Hukum Tata Negara (HTN). Fakultas Ushuluddin dan Dakwah (FUD) terdiri dari program Studi Ilmu Alquran Dan Tafsir (IAT) serta Komunikasi dan Penyiaran Islam (KPI). Fakultas Ekonomi dan Bisnis Islam terdiri dari Program Studi Perbankan Syariah (PS) dan Ekonomi Syariah.Semua (EKSYAR). Program Studi tersebut sudah terakreditasi. Pada tiga terakhir tahun ini Program Studi di IAIN Bone mengalami perkembangan karena salah satu dari 12 Program Studi tersebut yakni pada tahun 2018 Prodi Pendidikan Agama Islam memperoleh nilai akreditasi A yang sebelumnya nilai akreditasi B. Ditahun yang sama terjadi penambahan satu fakultas dan prodi. Untuk Strata Dua terdiri tiga prodi, yaitu Prodi Pendidikan Agama Islam, Prodi Hukum Tata Negara, dan Prodi Ekonomi Syariah.

Setelah melalui proses transformasi menjadi IAIN Pare-Pare, ada distingsi/pembeda dengan Institusi lainnya, yakni Akulturasi Islam-Budaya Berbasis Teknologi Informasi sehingga kedepannya Institusi ini akan menjadi pusat kajian Global Islam dalam kaitannya dengan Islam dan kebudayaan berbasis Teknologi Informas. Perubahan status harus menjadi semangat dalam melakukan inovasi. Pengelolaan harus lebih akuntabel, profesional, dan sistem administrasi dan manajemen lebih ditata secara modern dan kapasitas sumber daya manusia harus ditingkatkan. IAIN Pare-Pare memiliki tiga fakultas, yaitu fakultas Tarbiyah (FAKTAR), fakultas Syariah dan Hukum Islam. (FAKSHI), Fakultas Ushuluddin dan Adab dan Adab (FUAD), Fakultas Ekonomi dan Bisnis (FEBI). program Studi FAKTAR membina Pendidikan Agama Islam, Pendidikan Bahsa Arab, Tadris Bahasa Inggris, Tadris Matematika, Tadris Ilmu Pengetahuan Sosial, Pendidikan Islam Anak Usia Dini, Manajemen Pendidikan Islam, Tadris Ilmu Pengetahuan Alam. FAKSHI membina Program Studi: Hukum Keluarga Islam (Akhwalul Asy-Syahkhshiyah), Hukum Pidana Islam, Hukum Ekonomi Syariah (Muamalah), dan Hukum Tatanegara (Siyasah). FUAD membina program Studi: Sosial Agama, Komunikasi Penyiaran Islam, Manajemen Dakwah, 
Bimbingan Konseling Islam, Pengembangan Masyarakat Islam, Sejarah Kebudayaan Islam, dan Jurnalistik Islam. FEBI membina program Studi: Akuntasi Lembaga Keuangan Syariah, Akuntasnsi Syariah, Ekonomi Syariah, Manajemen Keuangan Syariah, Manajemen Zakat dan Wakaf, Pariwisata Syariah, dan Perbankan Syariah. Program Studi Di IAIN Pare-Pare sudah melakukan penambahan Program Studi sebelum beralih status.

Berdasarkan data yang diperoleh, maka dapat diketahui bahwa terdapat penambahan Program Studi di IAIN Bone dan IAIN Pare-Pare. Hal ini merupakan salah satu indikator bahwa telah terjadi perubahan di Perguruan Tinggi tersebut disebabkan adanya kepemimpinan yang teransformatif, kemauan dan kerjasama dari berbagai pihak yang terkait. Begitupula berdasarkan analisis dokumen dan wawancara maka diketahui bahwa Kurikulum Program Studi ) di IAIN Bone dan IAIN Pare-Pare sudah berbasis Kerangka Kualifikasi Nasional Indonesia (KKNI). Muatan mata kuliah Program Studi dan proses pembelajaran mengarah pada pencapian masing-masing profil Program Studi. Namun satu hal yang menjadi catatan bagi peneliti bahwa, Pembelajaran yang berbasis Informasi Tekhnolgi masih perlu ditingkatkan.

Dalam upaya meningkatkan Kompetensi Lulusan Program Studi, maka berbagai pengalaman diberikan kemahasiswa baik dalam kelas, maupun di masyarakat. Di samping itu, juga berbagai ujian yang harus dilewati oleh mahasiswa diantaranya ujian mata kuliah, ujian komprehensif, ujian proposal skripsi, dan ujian akhir skripsi. Pelaksanaan ujian tersebut sudah diatur dalam Standar Operasional Prosedur. Mahasiswa selama kuliah didampingi oleh Dosen Penasehat akademik (PA). Dosen tersebut berkewajiban membimbing mahasiswa agar sukses dalam studinya. Dosen pembimbing tidak berubah selama masih berstatus mahasiswa, kecuali dalam kondisi tertentu seperti dosen tersebut tugas belajr, meninggal, sakit menahun atau yang sejenis. Tidak berubahnya dosen pembimbing dimaksudkan agar dosen Penasehat Akademik dapat memantau perkembangan studi mahasiswa. Oleh sebab itu, mahasiswa diharapkan berkonsultasi dengan dosen pembimbing secara berkesinambungan.

Berikut ini tugas dosen Penasehat Akademi adalah sebagai berikut:

a. Membantu mahasiswa dalam menyusun rencana studi.

b. Memantau perkembangan studi mahasiswa.

c. Memberikan bimbingan dan nasehat kepada mahasiswa mengenai tata cara belajar yang baik dalam rangka menyelesaikan studi.

d. Memberikan pertimbangan dan atau persetujuan atas perubahan kartu rencana studi dan pengisian KRS yang diubah.

e. Memberikan solusi terhadap permasalahan akademik dan non akademik.

f. Menimal tiga kali bimbingan dalam satu semester.

c. Pelaksanaan Penelitian dan Pengabdian Masyarakat.

Perguruan tinggi berkewajiban menyelenggarakan pendidikan, penelitian dan pengabdian kepada masyarakat di samping sebagaimana diamanahkan oleh Undang-Undang Nomor 20 Tahun 2003 tentang Sistem Pendidikan Nasional Pasal 20. Sejalan dengan kewajiban tersebut, UndangUndang Nomor 12 Tahun 2012 tentang Pendidikan Tinggi Pasal 45 menegaskan bahwa penelitian di Perguruan Tinggi diarahkan untuk mengembangkan ilmu pengetahuan dan teknologi, serta meningkatkan kesejahteraan masyarakat dan daya saing bangsa. Dalam pasal tersebut juga ditegaskan bahwa pengabdian kepada masyarakat merupakan kegiatan civitas akademika dalam mengamalkan dan membudayakan ilmu pengetahuan dan teknologi untuk memajukan kesejahteraan umum dan mencerdaskan kehidupan bangsa. Sejalan dengan perannya sebagai fasilitator, penguat, dan pemberdaya, Ditjen Penguatan Riset dan Pengembangan (Ditjen Risbang) berupaya terus mengawal penelitian dan pengabdian kepada masyarakat di perguruan tinggi. Pengelolaan penelitian dan pengabdian kepada masyarakat di perguruan tinggi diarahkan untuk: 
1. Mewujudkan keunggulan penelitian dan pengabdian kepada masyarakat di perguruan tinggi.

2. Meningkatkan daya saing perguruan tinggi di bidang penelitian dan pengabdian kepada masyarakat pada tingkat nasional dan internasional.

3. Meningkatkan angka partisipasi dosen/peneliti dalam melaksanakan penelitian dan pengabdian kepada masyarakat yang bermutu.

4. Meningkatkan kapasitas pengelolaan penelitian dan pengabdian kepada masyarakat di perguruan tinggi.

5. Memfungsikan potensi perguruan tinggi dalam menopang daya saing bangsa.

Dosen IAIN Bone dan IAIN Pare-Pare di pacu dalam kegiatan penelitian. Penelitian dua tahun terakhir ini berbeda dengan tiga tahun yang lalu karena dilakukan sistem online dan diperiksa oleh reviewer nasional dari berbagai Perguruan Tinggi Islam. Output dari penelitian tersebut berupa buku, HAKI, Jurnal, Modul, look book dan laporan penelitian. Dari hal tersebut nantinya akan menambah nilai akreditasi institusi dan Program Studi.

Salah satu output hasil penelitian dosen adalah terpublikasi dijurnal. Jurnal IAIN Bone mengalami perkembanga dengan pesat. Di tahun 2019, empat Jurnal IAIN Bone terakreditasi sinta dan selebihnya terus dimaksimalkan pengelolaanya dengan target bisa terakreditasi sinta secara keseluruhan. Pada tahun 2018, masih ada jurnal di IAIN Bone masih manual pengelolaan, tetapi di tahun 2019 semua jurnal berbasis online. Bukti keseriusan dalam meningkatkan pengelolaan jurnal IAIN Bone maka telah dibentuk rumah jurnal. Begitupula Berdasarkan penelusuran dokumen, jurnal di IAIN Pare-Pare terdiri dari 11 Jurnal dan lima diantara terakreditasi sinta.

Selain penelitian, pengabdian masyarakat juga dilaksanakan DI IAIN Bone dan IAIN Pare-Pare. Pengabdian masyarakat di IAIN Bone dilaksanakan oleh LP2M, fakultas dan prodi. Berdasarkan penulusuran dokumen, di tahun 2018 Dosen IAIN Bone melakukan pendampingan masyarakat dalam pemanfaatan lahan pertanian di wilayah Ulaweng untuk tanaman cabe. Pendampingan yang dilakukan dalam rangka program pengabdian masyarakat itu sekaligus menjadi ruang uji coba pupuk organik racikan dosen IAIN Bone.

b. Mutu Pengelolaan bidang Non Akademik

1. Pengelolaan Sumber Daya Manusia.

Manusia adalah ciptaan Allah, yang mempunyai kedudukan yang sangat tinggi di antara makhluk Allah yang lain/ bahkan malaikat pun diperintahkan untuk sujud kepadanya. Melalui pengajaran Allah kepada Adam, manusia mampu untuk mengetahu huklum-hukum alam, dan melalui penundukkan Allah terhadap alam raya, manusia dapat memanfaatkan seluruh jagat raya, sebagaimana Firman Allah dalam QS Al-Jatsiyah (45) : 12.

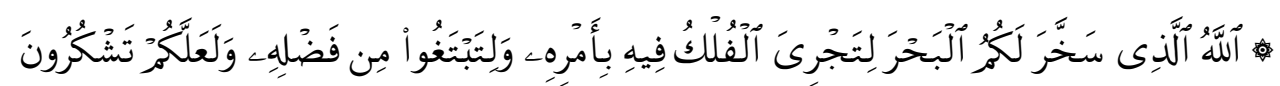

Terjemahnya : Allah-lah yang menundukkan lautan untukmu supaya kapal-kapal dapat berlayar padanya dengan seizin-Nya dan supaya kamu dapat mencari karunia-Nya dan Mudah-mudahan kamu bersyukur. ${ }^{11}$

Berdasarkan ayat di atas maka, Allah swt menyatakan bahwa Dia-lah yang menundukkan lautan untuk keperluan manusia sendiri. Hal ini berarti bahwa Allah menciptakan lautan itu hanyalah untuk manusia.

Saat ini manajemen strategi pengembangan Sumber Daya Manusia (SDM) telah mendapat perhatian besar, karena faktor penentu keberhasilan suatu institusi, lembaga, atau perusahaan

\footnotetext{
${ }^{11}$ Departemen Agama RI, Al-Quran dan Terjemahnya (Jakarta : doa Ibu, 2006), h. 28.
} 
ditentukan oleh SDM nya. Oleh karena itu, Kedua Perguruan Tinggi ini melakukan perencanaan stratrgi dalam meningkatkan SDM baik dari segi kantitatif maupun kualitatif. Berdasarkan data dari kepegawaian IAIN Bone diketahui bahwa terjadi penambahan jumlah dosen. Pada tahun 2018 penambahan dosen PNS sejumlah 8 orang sedangkan ditahun 2019 penambahan dosen sejumlah 33 orang dan 4 pegawai. Jadi jumlah PNS dosen di IAIN Bone yaitu 139 orang dan pegawai sejumlah 58 orang. Untuk Dosen Tetap Non PNS di IAIN Bone berjumlah 27 orang dan di tahun 2019 sudah dilakukan perekrutan namun masih menunggu penerbitan Surat Keputusan. Di samping itu, berdasarkan dokumen rekapitulasi ketenagaan IAIN Pare-Pare, diketahui bahwa pada saat ini IAIN Pare-Pare memilki Dosen PNS sejumlah 104 orang, dosen CPNS 31 orang. Jumlah pegawai PNS yaitu 43 orang dan Calon Pegawai (CAPEG) 4 orang. Dosen Tetap Non PNS sejumlah 70 orang, serta tenaga kontrak 77 orang.

Berdasarkan penelitian, diketahui jumlah dosen masih perlu ditambah mengingat belum terjadi rasio keseimbangan jumlah dosen dan mahasiswa. Begitupula dengan perubahan status ke IAIN, maka perlu penambahan pegawai. Lebih lanjut, upaya pengembangan kompetensi semua SDM di IAIN Bone dan IAIN Pare-Pare, maka telah dilakukan berbagai bentuk kegiatan diantaranya, kegiatan studi banding, pendidikan dan latihan, worshop, dan seminar, dan lain sebagainya.

Pelatihan merupakan wahana untuk membangun Sumber Daya Insani menuju era globalisasi yang penuh dengan tantangan. Berkaitan dengan hal tersebut, disadari bahwa pelatihan juga merupakan fundamental bagi SDM. Oleh karena itu, kegiatan pelatihan, workshop, seminar dan lainnya tidak dapat diabaikan begitu saja terutama dalam memasuki era persaingan yang semakin ketat, tajam, berat, pada abad melenium ini.

2. Pengelolaan sarana dan prasarana

Keberadaan sarana dan prasarana mutlak dibutuhkan dalam proses pendidikan. Tanpa sarana prasarana pendidikan, proses pendidikan akan mengalami kesulitan yang sangat serius, bahkan bisa menggagalkan pendidikan. Sarana pendidikan adalah peralatan dan perlengkapan yang secara langsung dipergunakan dalam proses belajar mengajar, seperti gedung, ruang kelas, meja kursi, serta media pengajaran. Adapun prasarana pendidikan adalah fasilitas secara tidak langsung menunjang jalannya proses pengajaran, seperti halaman, kebun, taman, dan jalan menuju kampus. Oleh karena itu, perlumnya manajemen sarana prasarana guna mengatur serta menjaga sarana prasaarana pendidikan agar dapat memberikan kontribusi pada proses pendidikan secara optimal dan berarti. Kegiatan pengelolaan ini meliputi kegiatan perencanaan, pengadaan, pengawasan, penyimpanan, inventarisasi, penghapusan, serta penataan.

Berdasarkan hasil analisis penelitian, adapun pengadaan barang dan jasa di kedu perguruan tinggi tersebut mengacu pada Perpres No 16 tahun 2018. Sarana prasarana IAIN Bone mengalami perkembangan. Pada tahun 2017 dilakukan pengadaan Laboratorium Terpadu, Gedung Dosen, dan Gedung Kuliah. Pada tahun 2018, pengadaan Gedung Fakultas Ekonomi dan Bisnis (FEBI). Adapun rehab di tahun 2018 yaitu; Gedung Dosen, Koridor Perpustakaan, Gedung Perpustakaan, Gedung Kuliah, Ruang Kepala Biro, Gedung Pusat Kegiatan Mahasiswa (PKM), Gedung Lembaga Penjaminan Mutu (LPM), Gedung Unit Tekhnologi Informasi Pangkalan Data (UTIPD), dan Gedung Pasca. Ditahun 2019, pengadaan Gedung Ma'had ALi dan pembangunan jalan kampus dua. Adapau rehab di tahun 2019 yaitu; Gedung Tarbiyah, Gedung Syariah, Gedung Kuliah, dan Gedung Layanan Akademik. Menurut Andi Nuzul bahwa, mahasiswa yang akan menempati Ma'had Ali adalah mahasiswa yang telah terselekasi, siap menghafal Al Quran. Tempat ini pula dijadikan wadah pelatihan muballig dan muballigah sehingga akan menjadi nilai jual IAIN Bone.

Dari penjelasan tersebut diketahui bahwa, sarana parasarana IAIN Bone mengalami perubahan dan penambahan baik pengadaan maupun rehabilitasi. Dan hal tersebut diperjelas dari 
observasi yang dilakukan oleh peneliti bahwa ada perubahan dan perkembangan yang begitu pesat namun fasilitas Informasi dan teknologi masih perlu dibenahi seperti penambahan server sehingga tidak lagi terjadi kelambatan atau gangguan dalam melakukan pelayanan akademik. LCD dan mobiler kelengkapan fakultas dan prodi masih perlu ditambah dan disesuaikan dengan kebutuhan serta pengadaan fasilitas Himpunan Mahasiswa Prodi.

Adapun pembangunan di IAIN Pare-Pare yang bersumber dari dana SBSN di tahun 2019 adalah pembangunan gedung Akademik Center yang berfungsi sebagai gedung Rektorat dan Akademik. Desain gedung ini berbentuk dua gedung kembar berlantai dan berlantai empat. Di tahun 2018, pembangunan gedung perkuliahan Fakultas Tarbiyah, gedung terpadu Fakultas Syariah dan Ilmu Hukum Islam dan Gedung Auditorium.

Oleh karena itu, perubahan dan perkembangan di IAIN Bone dan IAIN Pare-Pare sangat dipengaruhi oleh dukungan, semangat, kerjasama, dan motivasi dari stakeholder.

\section{KESIMPULAN DAN SARAN}

\section{Kesimpulan}

a. Pendekatan kepemimpinan dalam peningkatan mutu Perguruan Tinggi di IAIN Bone dan IAIN Pare-Pare adalah menerapkan nilai-nilai islami seperti fathonah, siddiq, amanah, tabliqh baik dalam melaksanakan tanggung jawabnya, pembagian kerja dan pengarahan, pengambilan keputusuan, pemberian insentif, dan pemberian hukuman. Selain itu, juga menerapkan budaya yang islami yaitu sipakatau, sipakainge dan sipakalebbi, malebbi warekkadana makkeade ampena.

b. Mutu Perguruan Tinggi di IAIN Bone dan IAIN Pare-Pare megalami perkembangan baik Akademik Maupun Non Akademik seperti ketersediaan kurikulum dan proses pembelajaran yang mengarah pada peningkatan kompetensi lulusan, peningkatan sarana dan prasarana, penambahan jumlah ketenagaan yang ditunjang pengetahuan dan keterampilan. Namun dengan terjadinya perubahan status dan perubahan standar pengelolaan Paerguruan Tinggi maka pembenahan senantiasa dilakukan dengan melibatkan stakeholder Perguruan Tinggi.

\section{Saran-Saran}

a. Diharapkan dukungan dan kerjasama yang maksimal dari stakeholder internal dan eksternal dalam pengembangan pengelolaan Perguruan Tinggi karena tanpa dukungan dari semua pihak maka tidak akan terjadi perubahan yang maksimal. Oleh karena itu dalam melaksanakan tugas pokok dan fungsi tetap mengedepankan professional kerja.

b. Perlu penambahan tenaga dosen sehingga terjadi rasio keseimbangan dengan mahasiswa.

c. Perlu penambahan pegawai guna memenuhi kebutuhan unit-unit kerja

d. Perlu penambahan sarana prasarana mengingat minat masyarakat semakin tinggi terhadap Perguruan Tinggi Islam.

\section{DAFTAR RUJUKAN}

Al-Munawi, Faidhul Qadir, juz 1, Darul Fikr, Beirut, cetakan 1, 1416H/ 1996M.

Ahmad, Dzaujak, Penunjuk Peningkatan Mutu pendidikan di sekolah Dasar, Jakarta: Depdikbud, 1996.

Ali, Atabik dan Ahmad Zuhdi Mudlor, Kamus Kontemporer Arab Indonesia, Yokyakarta: Yayasan Ali Maksum, 2005. 
Aziz A, Abdul. Sachedina dkk, Masalah-masalah Teori Politik Islam, Bandung: Mizan.

Daryanto, H. M, Administrasi Pendidikan, Jakarta : Rineka Cipta, 2005.

Departemen Pendidikan Nasional, Kamus Besar Bahasa Indonesia, 2002.

Dirawat dkk, Pengantar Kepemimpinan Pendidikan, Surabaya : Usaha Nasional, 1986.

Departemen Agama RI, Al-Quran dan Terjemahnya Jakarta : Doa Ibu, 2006.

Hornby, AS, Oxford Advance Leaners"s Dictionary, Oxford: Oxford University Press, 1995.

Juni Donni Priansa dan Rismi Somad, 2014. Manajemen Supervisi dan Kepemimpinan Kepala Sekolah (Alfabeta, 2014), h.11.

M.Darwan Raharjo, Ensiklopedi Al-Qur"an: Tafsir Sosial Berdasarkan Konsep-Konsep Kunci, Jakarta: Paramadina, 1996.

Marno dan Triyo supriyanto, Manajemen kepemimpinan pendidikan Islam, Refika Aditama, 2008.

Nata, Abuddin, Manajemen Pendidikan: Mengatasi kelemahan Pendidikan Islam di Indonesia ,Jakarta: Prenada Media, 2003.

Nawawi, Hadari, Administrasi Pendidikan, Jakarta : Haji Masagung, 1988.

Noor, Juliansyah, Penelitian Ilmu Manajemen, Cet. I; Jakarta: Kencana, 2013.

Poerwadarminta, W. J. S, Kamus Umum Bahasa Indonesia, Jakarta: Bumi Aksara, 2007.

Qomar, Mujamil. 2007. Manajemen Pendidikan Islam.Eelangga, 2007.

RahmanDwitiohttps://tiohamdani.wordpress.com/2014/11/26/penghargaan-dan-hukuman-dalamorganisasi-perusahaan / diakses tgl 11 November 2019.

Soerkamto, Soerjono, Sosiologi Suatu Pengajar, Jakarta : PT.Grafindo Persada, 1990.

Sugiyono.Metodologi Penelitian Manajemen.Bandung: Alfabeta, 2013.

Suharsaputra, Uhar, Administrasi Pendidikan, Cet. I; Bandung: PT Refika Aditama, 2010.

Tholhah Hasan, Muhammad. Islam dan Maasalah Sumber Daya Manusia. Jakarta : Lantabora Press, 2003.

Usman, Husaini, Manajemen: Teori, Praktik, dan Riset Pendidikan, Jakarta: Bumi Aksara, 2006.

Wahyudi. Kepemimpinan kepala Sekolah, Bandung: Alfabeta. 2012. 